Geological Society, London, Special Publications

Palaeoseismology: historical and prehistorical records of earthquake ground effects for seismic hazard assessment

K. Reicherter, A. M. Michetti and P. G. Silva Barroso

Geological Society, London, Special Publications 2009; v. 316; p. 1-10 doi:10.1144/SP316.1

Email alerting service

Permission request

Subscribe click here to receive free email alerts when new articles cite this article

click here to seek permission to re-use all or part of this article

click here to subscribe to Geological Society, London, Special Publications or the Lyell Collection

Notes

Downloaded by on 2 September 2009 


\title{
Palaeoseismology: historical and prehistorical records of earthquake ground effects for seismic hazard assessment
}

\author{
K. REICHERTER ${ }^{1 *}$, A. M. MICHETTI ${ }^{2} \&$ P. G. SILVA BARROSO ${ }^{3}$ \\ ${ }^{1}$ Lehr- und Forschungsgebiet Neotektonik und Georisiken, Geowissenschaften, RWTH \\ Aachen, Lochnerstr. 4-20, D-52064 Aachen, Germany \\ ${ }^{2}$ Dipartimento di Scienze Chimiche e Ambientali, Università dellínsubria, \\ Via Valleggio 11, 22100 Como, Italy \\ ${ }^{3}$ Departamento de Geología, Universidad de Salamanca, Escuela Politécnica Superior de Ávila, \\ Avda. Hornos Caleros, 50. 05003-Ávila, Spain \\ *Corresponding author (e-mail: k.reicherter@nug.rwth-aachen.de)
}

This volume grew particularly out of two meetings held in 2006 (European Geosciences Union General Assembly 2006, Session TS4.4, '3000 years of earthquake ground effects in Europe: geological analysis of active faults and benefits for hazard assessment', Vienna, Austria, April 2006; and the ICTP/IAEA workshop on 'The conduct of seismic hazard analyses for critical facilities', Trieste, Italy, May 2006) that brought together geoscientists who have explored and studied palaeoseismicity and its environmental effects in several parts of the world. This publication contains 18 papers based on a selection of presentations, and addresses a wide range of topics related to both a) palaeoseismological studies, and b) the assessment of a new macroseismic intensity scale based only on the natural phenomena associated with an earthquake, that is the ESI 2007 scale.

In 1999, during the 15th INQUA (International Union for Quaternary Research) Congress in Durban, the Subcommission on Palaeoseismicity promoted the compilation of a new scale of macroseismic intensity based only on environmental effects. A working group including geologists, seismologists and engineers compiled a first version of the scale that was presented at the 16th INQUA Congress in Reno in 2003, and updated one year later at the 32nd International Geological Congress in Florence (Michetti et al. 2004). To this end, the INQUA TERPRO (Commission on Terrestrial Processes) approved a specific project (INQUA Scale Project 2007). The revised version was ratified during the 17th INQUA Congress in Cairns in 2007. This revised version of the scale, which is formally named the Environmental Seismic Intensity scale-ESI 2007, is composed of two parts.

(1) The definition of intensity degrees on the basis of coseismic ground effects (see Appendix). ESI 2007 is a 12-degree macroseismic scale (Michetti et al. 2007), which follows the same basic structure of the original MercalliCancani-Sieberg scale (MCS scale; Sieberg 1912), and of the subsequent, widely used, Modified Mercalli macroseismic scales MM-31; (Wood \& Neumann 1931) and MM56 (Richter 1958), MSK-64 (MedvedevSponheuer-Karnik scale; Medvedev et al. 1964), and EMS-98 (European Macroseismic Scale; Grünthal 1998).

(2) The guidelines, which aim at better clarifying: (i) the background of the scale and the scientific concepts that support the introduction of such a new macroseismic scale; (ii) the procedure to use the scale alone or integrated with damage-based, traditional scales; (iii) how the scale is organized; (iv) the descriptions of diagnostic features required for intensity assessment, and the meaning of idioms, colours and fonts.

The main advantage of the ESI 2007 scale is the classification, quantification and measurement of several known geological, hydrological, botanical and geomorphic features for different intensity degrees, differentiating two main categories of earthquake effects on the environment: (a) primary (fault surface ruptures and tectonic uplift/ subsidence); and (b) secondary (including ground cracks, slope movements, liquefaction processes, anomalous waves and tsunamis, hydrogeological anomalies, and tree shaking). Primary effects triggered by surface faulting are almost absent for intensity degrees below VIII, are characteristic, but moderate for intensities between VIII and X, and diagnostic for the stronger top intensities of XI and XII (Fig. 1). This differentiation subdivides the earthquakes into three main categories (A, B, C), in which the absence (A), occurrence (B) and dimensions $(\mathrm{B}, \mathrm{C})$ of fault surface offsets allow 
CHART OF THE INQUA ENVIRONMENTAL SEISMIC INTENSITY SCALE 2007-ESI 07

by The Spanish Working Group (modified from Silva et al. 2008)

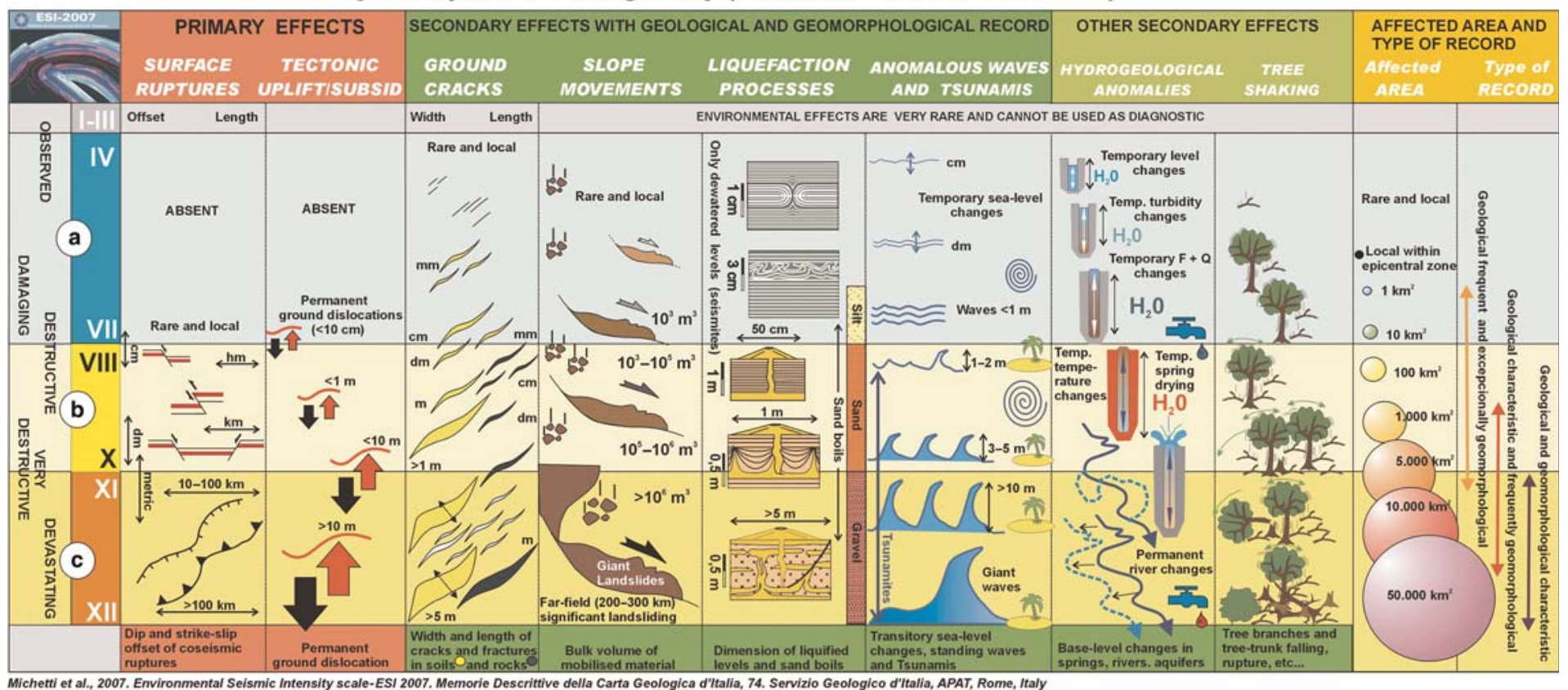

Silva et al., 2008. Catalogue of the geological and environmental effects of earthquakes in Spain in the ESI-2007 Macroseismic scale, Geotemas, 6. Spain

Fig. 1. The ESI 2007 chart summarizes the main features and dimensions of the more relevant Earthquake Environmental Effects (modified after Silva et al. 2008). 
the assignment of intensity to present and past seismic events. Complementarily, the dimension (width, length, volume of mobilized material) of secondary effects allows intensities to be constrained for type A and B earthquakes; while the extension of the area affected by secondary effects allows assessment of the epicentral intensity for type A, B and C earthquakes. Secondary effects are typically diagnostic for type B earthquakes, but frequently saturate for type $C$. In the same way primary effects are diagnostic for type $\mathrm{C}$ earthquakes, when structural damage to human constructions and engineering facilities saturate. In principle, both the total area affected by secondary effects and the dimensions (surface rupture length, displacement, amount of coseismic uplift or subsidence) of primary effects do not saturate for the large earthquakes. The combination of the ESI 2007 scale with other classic intensity scales (MSK, EMS, MM, MCS) helps to compare recorded structural damage with the dimension of observed or reported (past earthquakes) environmental effects, and consequently exports the obtained seismic records to past prehistoric events. Figure 1 summarizes the ESI 2007 chart (Silva et al. 2008), which illustrates the different categories of earthquakes as well as the main characteristic features for the different types of effects. Also, this chart gives a qualitative approach for the affected areas, type of geological and geomorphologic record, and their respective degree of preservation through time.

There is one very important aspect in introducing a new intensity scale into the practice. A great deal of work in seismic hazard assessment is accomplished in the world, and intensity is a basic parameter in this. Any 'new word' in this research field must not result in dramatic changes. Intensity VIII, for instance, has to mean more or less the same 'strength' of the earthquake, regardless of which macroseismic phenomena (anthropic or geological) it is assessed from. Obviously the ESI 2007 scale is not intended to replace the existing scales. We are simply affording a means to factor in the modifications induced by the earthquake on the physical environment, and then to compare them with the effects taken into account by other scales. There, indeed, the combined observations of widely varied effects is most likely to yield a more representative estimate of intensity, which in turn, using modern events as test cases, can then be collated with such instrumental measurements as magnitude and seismic moment. A more detailed description of the relationships between the ESI 2007 scales and the other scales is beyond the scope of this introduction; for a complete analysis of this point see Michetti et al. $(2004,2007)$.

The authors of this introduction do not ignore, however, that the use of macroseismic effects on natural surroundings is controversial. Over the past 40 years at least, proper attention has not been paid to these effects in estimating intensity, because they were reputed to be too variable, and likewise because they were not properly weighted in the scales. For example, recent data indicate that some phenomena occur, or start to occur, at degrees other than the ones they are assigned to in the scales: liquefaction, for instance, starts at lower intensities (VI-VII, or even V; e.g. Keefer 1984; Galli 2000; Porfido et al. 2002; Rodriguez et al. 2002) and not at VII or IX as indicated in most scales. We argue that the existence of similar inconsistencies in the available macroseismic scales should not lead to the conclusion that ground effects are useless for assessing earthquake intensity.

These uncertainties lead to an increasing lack of confidence in using ground effects as diagnostics, and progressively the effects on human perception and the anthropic environment (mainly buildings) became the only sensors analysed for intensity assessment. Exemplifying this logic, in the latest proposal by the European Seismological Commission to revise the MSK scale (Grünthal 1998), these effects are not reported in the scale per se, only in a brief appendix. We believe, however, that if this orientation is pursued, intensity will come to reflect mainly the economic development of the area that experienced the earthquake instead of its 'strength' (Serva 1994). It is also our belief that by ignoring ground effects, it will not be possible to assess intensity accurately in sparsely populated areas and/or areas inhabited by people with different modes of existence, such as nomads. This point has been very clearly made by Dengler \& McPherson (1993). The ESI scale is the logical extension of their approach. Furthermore the main problems arise for the highest degrees, XI and XII, where ground effects are the only ones that permit a reliable measurement of the severity of earthquake. All the scales, in fact, show that in this range of intensity ground effects predominate.

We believe the new ESI 2007 scale needs wider dissemination to allow a full scientific debate about its application to take place. One of the purposes of this Special Publication is thus to open the debate on a 'ground effects' scale for seismic hazard assessment.

It should be noted that the motivation for a new intensity scale based only on one class of macroseismic information, the effects on nature, rests exactly on the dramatic progress of our knowledge about the coseismic ground effects, and notably about surface faulting, gained in the last 30 years thanks to the growth of palaeoseismological studies. In the monograph Active Tectonics: Impacts on Society 
(Wallace 1986), the first book that can be regarded as an overview of palaeoseismology, several papers made absolutely clear the quantitative relations that link the physical phenomena induced by earthquakes in the natural environment and the earthquake size. It has become a global, standard practice for palaeoseismologists since the late 1970s to survey in the field immediately after an earthquake the distribution of landslides, liquefactions, hydrological changes, coastal uplift and subsidence, and especially the characters and dimensions of tectonic ground ruptures. This is particularly true for the environmental effects generated by large earthquakes that break the ground surface (e.g. Allen 1986). Today, for instance, we have about 40 large earthquakes for which the geometry of surface faulting and the slip distribution along the fault strike have been mapped in detail (Wesnousky 2008). In this way, ground effects can be estimated from observations and regression analyses of historical earthquakes and a) fault displacement (Slemmons \& dePolo 1986), b) liquefaction (Galli 2000), c) landslides (Keefer 1984), and several other features. This knowledge was not available at the time of early macroseismic scales, which very wisely included environmental effects in the different intensity degrees, but obviously without a detailed quantitative description due to the poor available dataset. There now exists an entirely new catalogue of information that allows us to update the macroseismic intensity observations by incorporating a wealth of palaeoseismological data. Vice-versa, the new macroseismic intensity scale based on environmental effects becomes a valuable tool and a guide for the palaeoseismologist. The lessons learned from intensity observations are educational for palaeoseismic analyses and interpretations, because they encourage the specialist to cross-check the results obtained using one particular evidence of palaeoseismicity. Once an ESI 2007 intensity degree has been assessed from a particular palaeoseismic feature, consistency with the whole spectrum of ground effects included in the same intensity degree should be ensured.

In our opinion, this illustrates quite well the scope of the present Special Publication and the basic idea behind all the presented contributions. The volume is divided into two sections. The first section focuses on the analysis of the coseismic ground effects from contemporary and historical earthquakes, and the implementation and refinement of the ESI 2007 scale. The second section is devoted to the analysis of individual case histories illustrating the different geological, geomorphological, geophysical techniques and field-survey methods used to identify causative and capable faults, and seismic hazard, from seismological and palaeoseismological approaches.
Papanikolaou et al. revise the macroseismic information for several earthquakes in Greece in order to calibrate the ESI 2007 scale against the traditional, damage-based scales. Their results show how the ESI 2007 scale, following the same criteria for all earthquakes, can compare not only events from different settings, but also contemporary and future earthquakes with historical events. This is of particular value for seismic hazard assessment in countries with a long record of seismicity such as Greece.

Two papers take advantage of a very large number of fault trench exposures to draw inference on earthquake hazard and fault behaviour along major strike-slip structures. Rockwell et al. illustrate extensive fault trenching across the trace of the coseismic ground ruptures associated with the large earthquakes of 9 August 1912 and 17 August 1999 along the North Anatolian Fault, west and east of the Marmara Sea, respectively. This allows better resolution of the history of surface ruptures for the past 400 years around Istanbul. A better quantitative assessment of coseismic environmental effects such as fault displacement is critical for the mitigation of earthquake risk in one of the largest metropolitan areas of the Earth.

Mouslopoulou et al. use fault data from 20 trenches to explore whether changes in late Quaternary fault kinematics principally arise due to earthquake rupture arrest and/or variations in slip vector pitch during individual earthquakes that span the kinematic transition zone occurring along the North Island Fault System, New Zealand, near the intersection with the active Taupo Rift.

Ground effects from four large earthquakes in Japan and Taiwan have been compiled by Ota et $\boldsymbol{a l}$. in order to assess the ESI 2007 scale. The new resulting maps show more detailed intensity patterns than those previously available for the four areas. Calibration exercise also reveals, however, that the ESI 2007 intensity scale needs some methodological improvement. This is somewhat expected and is needed for the better implementation of this new intensity scale in the future.

A similar exercise is proposed by Tatevossian et al., who used examples from the Altai (27 September 2003) and the Neftegorsk (27 May 1995) earthquakes. One of the main points made by these authors is the relevance of the environmental effects for intensity assessment in the near field of strong earthquakes. We argue that this is the very fundamental concept which provides reliable relations between palaeoseismology, macroseismic intensity and seismic hazard assessment. The results of Tatevossian et al. should be compared with those presented by Ota et al., MosqueraMachado et al. and Zahid et al. The epicentral 
intensity $\left(\mathrm{I}_{0}\right)$ based on the ESI 2007 scale can be two to four times higher than $\mathrm{I}_{0}$ assessed without taking into account the ground effects. This indicates that by excluding the environmental effects, especially primary effects, we not only miss a valuable piece of information, sometimes the only one available in sparsely populated areas, but we are also missing the low frequency (static) part of an earthquake impact. In the epicentral area of strong seismic events, where the static offset reaches the order of several metres, intensity assessments ignoring this component are useless.

The integrated identification and analysis of archeoseismic and palaeoseismic evidence at the Roman site of Baelo Claudia, Gibraltar Strait (south Spain), is the purpose of the work by Silva et al. These authors combine observations on damage and secondary environmental effects in order to assess the local seismic hazard in terms of expected recurrence of intensity values within a specific time window.

A similar potential archeoseismic case history in a region with moderate seismicity is presented by Hinzen \& Weiner, who apply geotechnical modelling to test the coseismic hypthesis for the damage to a Neolithic wooden well recently excavated near Erkelenz, in the Lower Rhine Embayment (NW Germany).

Two papers revise earthquake ground effects and active faulting in sparsely populated regions. Mosquera-Machado et al. studied the Mw 7.3 Murindo earthquake (18 October 1992) in NW Colombia, which provides relevant data for the application of the ESI 2007 scale. The resulting new isoseismal map is relevant for the assessment of future seismic risk in this part of Colombia where intensity assessment based on traditional damage-based scales cannot give a detailed picture of the earthquake severity. The Mw 7.8 Kunlun earthquake (14 November 2001) occurred in northern Tibet, in a remote, high-mountain region. Lin \& Guo documented for the first time the palaeoseismic history of this region based on evidence of liquefaction within the trace of the 450-km-long surface rupture zone generated by this large event.

The analysis of the coseismic effects on the natural environment along the 110-km-long zone of surface thrust faulting associated with the M 7.6 Muzaffarabad, Pakistan, earthquake of 8 October 2005, is the topic covered by Ali et al., also discussed from the seismotectonic point of view by MonaLisa. The macroseismic intensity distribution for this event shows a remarkable correlation with the trace of the surface rupture. Near Muzaffarabad, intensity XI in the MM, EMS-98 and ESI 2007 scales has been consistently assessed at sites where maximum values of fault displacement (in the order of $4 \mathrm{~m}$ ) were observed.
Both Gregersen \& Voss and Mörner provide a comprehensive seismological and palaeoseismological framework for the understanding and interpretation, in terms of seismic hazard, of the remarkable evidence of post-glacial palaeoseismicity available in Scandinavia.

A particular category of ground effects, that is found in the endokarstic terrains, is explored by Pérez-López et al., starting from the observation of the collapse that occurred within the Benis Cave (-213 m; Murcia, SE Spain), during the Mula earthquake $(\mathrm{mb}=4.8$, MSK VII, 2 February 1999).

Also in SE Spain (Almería Region), the stratigraphic and sedimentological evidence of past tsunamis in the western Mediterranean is discussed by Reicherter \& Becker-Heidmann. The authors used shallow drilling in the lagoon of Cabo de Gata for identifying possible tsunamites associated with the 1522 Almería earthquake.

Trenching along the Vilariça segment of the Manteigas-Bragança Fault in NE Portugal, allows Rockwell $\boldsymbol{e t} \boldsymbol{a l}$. to identify evidence of a cluster of surface faulting earthquakes in the latest Pleistocene to early Holocene. This holds relevant implications for the seismic hazard of this region, characterized by moderate historical seismicity. Likewise, White et $\boldsymbol{a l}$. discuss the evidence for recent activity and related seismic hazard along the Hebron Fault in SW Namibia, within a stable continental area.

In summary, the set of papers included in this volume is basically devoted to the analysis of environmental earthquake effects linked to recent, past and prehistoric strong seismic events. The understanding of the type and dimensions of earthquake ground effects linked to different levels of seismic shaking and earthquake magnitude is the only prudent and consistent way to incorporate past strong events, only witnessed in the geological and geomorphological record, into the classic seismic catalogues, which are the basis of most of the seismic hazard studies and assessments. The efforts of the palaeoseismological community are directed to expanding back in time, and refining in terms of completeness, the seismic history of individual faults and/or seismic regions, in order to achieve a better understanding of the pulse (regularity and/or clustering) of seismic cycles in different tectonic settings, and its further implementation in hazard studies. Although the ESI 2007 scale is properly devoted to its application to past earthquakes, its application to recent events is critical, since it will allow refining the scale, and therefore improving maximum intensities recorded during past events. This volume offers to the scientific community a new tool to assign intensities, and a wide variety of geological methods to identify and measure earthquake environmental effects. 
Many thanks are due to the armada of reviewers, who help to shape and focus the scope of this volume (in alphabetical order): P. Alfaro, F. Audemard, J. Cabral, R. Caputo, J. Dolan, F. Dramis, M. Ferry, A. Gorshkov, L. Guerrieri, K. Hinzen, R. Jibson, E. Kagan, J. Lario, T. Little, B. Lund, S. Marco, E. Masana, B. Mohammadioun, K. Okumura, C. Pascal, S. Pavlides, L. Piccardi, S. Porfido, Y. Quinif, G. Roberts, M. Rodriguez Pascua, L. Serva, M. Sintubin, A. Smedile, B. Shyu, I. Stewart, V. Trifonov and J. van der Woerd.

\section{Appendix: ESI 2007 scale definition of intensity degrees}

Text in italic indicates effects that can be used directly to define an intensity degree.

\section{From I to III}

There are no environmental effects that can be used as diagnostic.

\section{Largely observed/First unequivocal effects in the environment}

Primary effects are absent.

\section{Secondary effects}

(a) Rare small variations of the water level in wells and/or of the flow rate of springs are locally recorded, as well as extremely rare small variations of chemical-physical properties of water and turbidity in springs and wells, especially within large karstic spring systems, which appear to be most prone to this phenomenon.

(b) In closed basins (lakes, even seas) seiches with height not exceeding a few centimetres may develop, commonly observed only by tidal gauges, exceptionally even by naked eye, typically in the far field of strong earthquakes. Anomalous waves are perceived by all people on small boats, few people on larger boats, most people on the coast. Water in swimming pools swings and may sometimes overflows.

(c) Hair-thin cracks (millimetre wide) might be occasionally seen where lithology (e.g. loose alluvial deposits, saturated soils) and/or morphology (slopes or ridge crests) are most prone to this phenomenon.

(d) Exceptionally, rocks may fall and small landslides may be (re)activated, along slopes where the equilibrium is already near the limit state, e.g. steep slopes and cuts, with loose and generally saturated soil.

(e) Tree limbs shake feebly.

\section{$V$ Strong/Marginal effects in the environment}

Primary effects are absent.

\section{Secondary effects}

(a) Rare variations of the water level in wells and/or of the flow rate of springs are locally recorded, as well as small variations of chemical-physical properties of water and turbidity in lakes, springs and wells.

(b) In closed basins (lakes, even seas) seiches with height of decimetres may develop, sometimes noted also by naked eye, typically in the far field of strong earthquakes. Anomalous waves up to several tens of centimetres high are perceived by all people on boats and on the coast. Water in swimming pools overflows.

(c) Thin cracks (millimetre wide and several centimetres up to 1 metre long) are locally seen where lithology (e.g. loose alluvial deposits, saturated soils) and/or morphology (slopes or ridge crests) are most prone to this phenomenon.

(d) Rare small rockfalls, rotational landslides and slump earth flows may take place, along often but not necessarily steep slopes where equilibrium is near the limit state, mainly loose deposits and saturated soil. Underwater landslides may be triggered, which can induce small anomalous waves in coastal areas of sea and lakes.

(e) Tree limbs and bushes shake slightly, very rare cases of fallen dead limbs and ripe fruit.

(f) Extremely rare cases are reported of liquefaction (sand boil), small in size and in areas most prone to this phenomenon (highly susceptible, recent, alluvial and coastal deposits, near-surface water table).

\section{Slightly damaging/Modest effects in the environment}

Primary effects are absent.

\section{Secondary effects}

(a) Significant variations of the water level in wells and/ or of the flow rate of springs are locally recorded, as well as small variations of chemical-physical properties of water and turbidity in lakes, springs and wells.

(b) Anomalous waves up to many tens of centimetres high flood very limited areas nearshore. Water in swimming pools and small ponds and basins overflows.

(c) Occasionally, millimetre to centimetre-wide fractures and up to several metres long are observed in loose alluvial deposits and/or saturated soils; along steep slopes or riverbanks they can be 1-2 cm wide. A few minor cracks develop in paved (either asphalt or stone) roads.

(d) Rockfalls and landslides with volume reaching c. $10^{3} \mathrm{~m}^{3}$ can take place, especially where equilibrium is near the limit state, e.g. steep slopes and cuts, with loose saturated soil, or highly weathered/ fractured rocks. Underwater landslides can be triggered, occasionally provoking small anomalous waves in coastal areas of sea and lakes, commonly seen by intrumental records.

(e) Trees and bushes shake moderately to strongly; a very few tree tops and unstable dead limbs may break and fall, also depending on species, fruit load and state of health. 
(f) Rare cases are reported of liquefaction (sand boil), small in size and in areas most prone to this phenomenon (highly susceptible, recent, alluvial and coastal deposits, near surface water table).

\section{Damaging/Appreciable effects in the environment}

Primary effects observed very rarely, and almost exclusively in volcanic areas. Limited surface fault ruptures, tens to hundreds of metres long and with centimetric offset, may occur, essentially associated with very shallow earthquakes.

Secondary effects. The total affected area is in the order of $10 \mathrm{~km}^{2}$.

(a) Significant temporary variations of the water level in wells and/or of the flow rate of springs are locally recorded. Seldom, small springs may temporarily run dry or appear. Weak variations of chemicalphysical properties of water and turbidity in lakes, springs and wells are locally observed.

(b) Anomalous waves even higher than a metre may flood limited nearshore areas and damage or wash away objects of variable size. Water overflows from small basins and watercourses.

(c) Fractures up to 5-10 cm wide and up to a hundred metres long are observed, commonly in loose alluvial deposits and/or saturated soils; rarely in dry sand, sand-clay, and clay soil fractures, up to $1 \mathrm{~cm}$ wide. Centimetre-wide cracks are common in paved (asphalt or stone) roads.

(d) Scattered landslides occur in prone areas, where equilibrium is unstable (steep slopes of loose/saturated soils), while modest rock falls are common on steep gorges, cliffs). Their size is sometimes significant $\left(10^{3}-10^{5} \mathrm{~m}^{3}\right)$; in dry sand, sand-clay and clay soil, the volumes are usually up to $100 \mathrm{~m}^{3}$. Ruptures, slides and falls may affect riverbanks and artificial embankments and excavations (e.g. road cuts, quarries) in loose sediment or weathered/fractured rock. Significant underwater landslides can be triggered, provoking anomalous waves in coastal areas of sea and lakes, directly felt by people on boats and ports.

(e) Trees and bushes shake vigorously; especially in densely forested areas, many limbs and tops break and fall.

(f) Rare cases are reported of liquefaction, with sand boils up to $50 \mathrm{~cm}$ in diameter, in areas most prone to this phenomenon (highly susceptible, recent, alluvial and coastal deposits, near surface water table).

\section{Heavily damaging/Extensive effects in the environment \\ Primary effects are observed rarely. \\ Ground ruptures (surface faulting) may develop, up to several hundred metres long, with offsets not exceeding}

a few centimetres, particularly for very shallow focus earthquakes such as those common in volcanic areas. Tectonic subsidence or uplift of the ground surface with maximum values on the order of a few centimetres may occur.

Secondary effects. The total affected area is in the order of $100 \mathrm{~km}^{2}$.

(a) Springs may change, generally temporarily, their flow rate and/or elevation of outcrop. Some small springs may even run dry. Variations in water level are observed in wells. Weak variations of chemicalphysical properties of water, most commonly temperature, may be observed in springs and/or wells. Water turbidity may appear in closed basins, rivers, wells and springs. Gas emissions, often sulphurous, are locally observed.

(b) Anomalous waves up to 1-2 metres high flood nearshore areas and may damage or wash away objects of variable size. Erosion and dumping of waste is observed along the beaches, where some bushes and even small weak-rooted trees can be uprooted and drift away. Water violently overflows from small basins and watercourses.

(c) Fractures up to $50 \mathrm{~cm}$ wide are and up to hundreds of metres long commonly observed in loose alluvial deposits and/or saturated soils; in rare cases fractures up to $1 \mathrm{~cm}$ can be observed in competent dry rocks. Decimetric cracks common in paved (asphalt or stone) roads, as well as small pressure undulations.

(d) Small to moderate $\left(10^{3}-10^{5} \mathrm{~m}^{3}\right)$ landslides are widespread in prone areas; rarely they can occur also on gentle slopes. Where equilibrium is unstable (steep slopes of loose/saturated soils; rock falls on steep gorges, coastal cliffs) their size is sometimes large $\left(10^{5}-10^{6} \mathrm{~m}^{3}\right)$. Landslides can occasionally dam narrow valleys causing temporary or even permanent lakes. Ruptures, slides and falls affect riverbanks and artificial embankments and excavations (e.g. road cuts, quarries) in loose sediment or weathered fractured rock. Frequent occurrence of landslides below sea level in coastal areas.

(e) Trees shake vigorously; branches may break and fall, trees even uprooted, especially along steep slopes.

(f) Liquefaction may be frequent in the epicentral area, depending on local conditions; sand boils up to c. $1 \mathrm{~m}$ in diameter; apparent water fountains in still waters; localized lateral spreading and settlements (subsidence up to c. $30 \mathrm{~cm}$ ), with fissuring parallel to waterfront areas (river banks, lakes, canals, seashores).

(g) In dry areas, dust clouds may rise from the ground in the epicentral area.

(h) Stones and even small boulders and tree trunks may be thrown in the air, leaving typical imprints in soft soil. 


\section{Destructive/Effects in the environment are a widespread source of considerable hazard and become important for intensity assessment}

Primary effects are observed commonly.

Ground ruptures (surface faulting) develop, up to a few kilometres long, with offsets generally in the order of several centimetres. Tectonic subsidence or uplift of the ground surface with maximum values in the order of a few decimetres may occur.

Secondary effects. The total affected area is in the order of $1000 \mathrm{~km}^{2}$.

(a) Springs can change, generally temporarily, their flow rate and/or location to a considerable extent. Some modest springs may even run dry. Temporary variations of water level are commonly observed in wells. Water temperature often changes in springs and/or wells. Variations of chemical-physical properties of water, most commonly temperature, are observed in springs and/or wells. Water turbidity is common in closed basins, rivers, wells and springs. Gas emissions, often sulphurous, are observed, and bushes and grass near emission zones may burn.

(b) Waves several metres high develop in still and running waters. In flood plains water streams may even change their course, also because of land subsidence. Small basins may appear or be emptied. Depending on shape of sea bottom and coastline, dangerous tsunamis may reach the shores with runups of up to several metres flooding wide areas. Widespread erosion and dumping of waste is observed along the beaches, where bushes and trees can be uprooted and drift away.

(c) Fractures up to $100 \mathrm{~cm}$ wide and up to hundreds of metres long are commonly observed in loose alluvial deposits and/or saturated soils; in competent rocks they can reach up to $10 \mathrm{~cm}$. Significant cracks are common in paved (asphalt or stone) roads, as well as small pressure undulations.

(d) Landsliding widespread in prone areas, also on gentle slopes; where equilibrium is unstable (steep slopes of loose/saturated soils; rock falls on steep gorges, coastal cliffs) their size is frequently large $\left(10^{5} \mathrm{~m}^{3}\right)$, sometimes very large $\left(10^{6} \mathrm{~m}^{3}\right)$. Landslides can dam narrow valleys causing temporary or even permanent lakes. Riverbanks, artificial embankments and excavations (e.g. road cuts, quarries) frequently collapse. Frequent large landslides below sea level in coastal areas.

(e) Trees shake vigorously; branches and thin tree trunks frequently break and fall. Some trees might be uprooted and fall, especially along steep slopes.

(f) Liquefaction and water upsurge are frequent; sand boils up to $3 \mathrm{~m}$ in diameter; apparent water fountains in still waters; frequent lateral spreading and settlements (subsidence of more than $c .30 \mathrm{~cm}$ ), with fissuring parallel to waterfront areas (river banks, lakes, canals, seashores).

(g) In dry areas, dust clouds commonly rise from the ground.

(h) Small boulders and tree trunks may be thrown in the air and move away from their site for metres, also depending on slope angle and roundness, leaving typical imprints in soft soil.

$X$ Very destructive/Effects on the environment become a leading source of hazard and are critical for intensity assessment

Primary effects become leading.

Surface faulting can extend for a few tens of kilometres, with offsets from tens of centimetres up to a few metres. Gravity grabens and elongated depressions develop; for very shallow focus earthquakes in volcanic areas rupture lengths might be much lower. Tectonic subsidence or uplift of the ground surface with maximum values in the order of a few metres may occur.

Secondary effects. The total affected area is in the order of $5000 \mathrm{~km}^{2}$.

(a) Many springs significantly change their flow rate and/or elevation of outcrop. Some springs may run temporarily or even permanently dry. Temporary variations of water level are commonly observed in wells. Even strong variations of chemical-physical properties of water, most commonly temperature, are observed in springs and/or wells. Often water becomes very muddy in even large basins, rivers, wells and springs. Gas emissions, often sulphurous, are observed, and bushes and grass near emission zones may burn.

(b) Waves several metres high develop in even big lakes and rivers, which overflow from their beds. In flood plains rivers may change their course, temporarily or even permanently, also because of widespread land subsidence. Basins may appear or be emptied. Depending on shape of sea bottom and coastline, tsunamis may reach the shores with runups exceeding $5 \mathrm{~m}$ flooding flat areas for thousands of metres inland. Small boulders can be dragged for many metres. Widespread deep erosion is observed along the shores, with noteworthy changes of the coastline profile. Trees nearshore are uprooted and drift away.

(c) Open ground cracks up to more than $1 \mathrm{~m}$ wide and up to hundreds of metres long are frequent, mainly in loose alluvial deposits and/or saturated soils; in competent rocks opening is reach several decimetres. Wide cracks develop in paved (asphalt or stone) roads, as well as pressure undulations.

(d) Large landslides and rock-falls $\left(>10^{5}-10^{6} \mathrm{~m}^{3}\right)$ are frequent, almost regardless of equilibrium state of the slopes, causing temporary or permanent barrier lakes. River banks, artificial embankments, and 
sides of excavations typically collapse. Levees and earth dams may even incur serious damage. Frequent large landslides below sea level in coastal areas.

(e) Trees shake vigorously; many branches and tree trunks break and fall. Some trees might be uprooted and fall.

(f) Liquefaction, with water upsurge and soil compaction, may change the aspect of wide zones; sand volcanoes even more than $6 \mathrm{~m}$ in diameter; vertical subsidence even $>1 \mathrm{~m}$; large and long fissures due to lateral spreading are common.

(g) In dry areas, dust clouds may rise from the ground.

(h) Boulders (diameter in excess of 2-3 $\mathrm{m}$ ) can be thrown in the air and move away from their site for hundreds of metres down even gentle slopes, leaving typical imprints in soil.

\section{Devastating/Effects on the environment become decisive for intensity assessment, due to saturation of structural damage}

\section{Primary effects are dominant.}

Surface faulting extends from several tens of kilometres up to more than one hundred kilometres, accompanied by offsets reaching several metres. Gravity graben, elongated depressions and pressure ridges develop. Drainage lines can be seriously offset. Tectonic subsidence or uplift of the ground surface with maximum values in the order of numerous metres may occur.

Secondary effects. The total affected area is in the order of $10000 \mathrm{~km}^{2}$.

(a) Many springs significantly change their flow rate and/or elevation of outcrop. Many springs may run temporarily or even permanently dry. Temporary or permanent variations of water level are generally observed in wells. Even strong variations of chemical-physical properties of water, most commonly temperature, are observed in springs and/or wells. Often water becomes very muddy in even large basins, rivers, wells and springs. Gas emissions, often sulphurous, are observed, and bushes and grass near emission zones may burn.

(b) Large waves develop in big lakes and rivers, which overflow from their beds. In flood plains rivers can change their course, temporarily or even permanently, also because of widespread land subsidence and landsliding. Basins may appear or be emptied. Depending on shape of sea bottom and coastline, tsunamis may reach the shores with runups reaching $15 \mathrm{~m}$ and more devastating flat areas for kilometres inland. Even metre-sized boulders can be dragged for long distances. Widespread deep erosion is observed along the shores, with noteworthy changes of the coastal morphology. Trees nearshore are uprooted and drift away.

(c) Open ground cracks up to several metres wide are very frequent, mainly in loose alluvial deposits and/or saturated soils. In competent rocks they can reach $1 \mathrm{~m}$. Very wide cracks develop in paved (asphalt or stone) roads, as well as large pressure undulations.

(d) Large landslides and rock-falls $\left(>10^{5}-10^{6} \mathrm{~m}^{3}\right)$ are frequent, practically regardless to equilibrium state of the slopes, causing many temporary or permanent barrier lakes. River banks, artificial embankments, and sides of excavations typically collapse. Levees and earth dams incur serious damage. Significant landslides can occur at 200-300 km distance from the epicentre. Frequent large landslides below sea level in coastal areas.

(e) Trees shake vigorously; many branches and tree trunks break and fall. Many trees are uprooted and fall.

(f) Liquefaction changes the aspect of extensive zones of lowland, determining vertical subsidence possibly exceeding several metres, numerous large sand volcanoes, and severe lateral spreading features.

(g) In dry areas dust clouds rise from the ground.

(h) Big boulders (diameter of several metres) can be thrown in the air and move away from their site for long distances down even gentle slopes, leaving typical imprints in soil.

\section{Completely devastating/Effects in the environment are the only tool for intensity assessment}

Primary effects are dominant.

Surface faulting is at least a few hundreds of kilometres long, accompanied by offsets reaching several tens of metres. Gravity graben, elongated depressions and pressure ridges develop. Drainage lines can be seriously offset. Landscape and geomorphological changes induced by primary effects can attain extraordinary extent and size (typical examples are the uplift or subsidence of coastlines by several metres, appearance or disappearance from sight of significant landscape elements, rivers changing course, origination of waterfalls, formation or disappearance of lakes).

Secondary effects. The total affected area is in the order of $50000 \mathrm{~km}^{2}$ and more.

(a) Many springs significantly change their flow-rate and/or elevation of outcrop. Temporary or permanent variations of water level are generally observed in wells. Many springs and wells may run temporarily or even permanently dry. Strong variations of chemical-physical properties of water, most commonly temperature, are observed in springs and/or wells. Water becomes very muddy in even large basins, rivers, wells and springs. Gas emissions, often sulphurous, are observed, and bushes and grass near emission zones may burn.

(b) Giant waves develop in lakes and rivers, which overflow from their beds. In flood plains rivers 
change their course and even their flow direction, temporarily or even permanently, also because of widespread land subsidence and landsliding. Large basins may appear or be emptied. Depending on shape of sea bottom and coastline, tsunamis may reach the shores with runups of several tens of metres devastating flat areas for many kilometres inland. Big boulders can be dragged for long distances. Widespread deep erosion is observed along the shores, with outstanding changes of the coastal morphology. Many trees are uprooted and drift away. All boats are torn from their moorings and swept away or carried onshore even for long distances. All people outdoors are swept away.

(c) Ground open cracks are very frequent, up to one metre or more wide in the bedrock, up to more than $10 \mathrm{~m}$ wide in loose alluvial deposits and/or saturated soils. These may extend up to several kilometres in length.

(d) Large landslides and rock-falls $\left(>10^{5}-10^{6} \mathrm{~m}^{3}\right)$ are frequent, practically regardless of equilibrium state of the slopes, causing many temporary or permanent barrier lakes. River banks, artificial embankments, and sides of excavations typically collapse. Levees and earth dams incur serious damage. Significant landslides can occur at more than 200-300 km distance from the epicentre. Frequent very large landslides below sea level in coastal areas.

(e) Trees shake vigorously; many branches and tree trunks break and fall. Many trees are uprooted and fall.

(f) Liquefaction occurs over large areas and changes the morphology of extensive flat zones, determining vertical subsidence exceeding several metres, widespread large sand volcanoes, and extensive severe lateral spreading features.

(g) In dry areas dust clouds rise from the ground.

(h) Very big boulders can be thrown in the air and move for long distances even down very gentle slopes, leaving typical imprints in soil.

\section{References}

ALLEN, C. R. 1986. Seismological and paleoseismological techniques of research in active tectonics. In: Wallace, R. E. (ed.) Active Tectonics: Impacts on Society. National Academy Press, Washington, D.C., Studies in Geophysics, 148-154.

Dengler, L. \& MCPherson, R. 1993. The 17 August 1991 Honeydew earthquake, North Coast California: a case for revising the Modified Mercalli scale in sparsely populated areas. Bulletin of the Seismological Society of America, 83, 1081-1094.

GALLI, P. 2000. New empirical relationships between magnitude and distance for liquefaction. Tectonophysics, 324, 169-187.

GRÜnthal, G. (ed.) 1998. European Macroseismic Scale 1998 (EMS-98). European Seismological Commission, Subcommission on Engineering Seismology, Working Group Macroseismic Scales. Conseil de l'Europe,
Luxembourg, Cahiers du Centre Européen de Géodynamique et de Séismologie, 15.

INQUA Scale Project, 2007. Available online at http:// www.apat.gov.it/site/en-GB/Projects/INQUA_Scale

KeEFER, D. K. 1984. Landslides caused by earthquakes. Geological Society of America Bulletin, 95, 406-421.

Medvedev, S., Sponheuer, W. \& Karník, V. 1964. Neue seismische Skala. 7. Tagung der Europäischen Seismologischen Kommission vom 24.9. bis 30.9 . 1962 in Jena, Veröff. Institut für Bodendynamik und Erdbebenforschung in Jena, Deutsche Akademie der Wissenschaften zu Berlin, 77, 69-76.

Michetti, A. M., Esposito, E. ET AL. 2004. The INQUA Scale. An innovative approach for assessing earthquake intensities based on seismically-induced ground effects in natural environment. In: VITTORI, E. \& Comerci, V. (eds) Special Paper, APAT, Memorie Descrittive della Carta geologica d'Italia, LXVII. SystemCart Srl, Roma, Italy.

Michetti, A. M., Esposito, E. ET AL. 2007. Environmental Seismic Intensity Scale 2007 - ESI 2007. In: VitTori, E. \& GUerrieri, L. (eds) Memorie Descrittive della Carta Geologica d'Italia, LXXIV. Servizio Geologico d'Italia, Dipartimento Difesa del Suolo, APAT, SystemCart Srl, Roma, Italy, 7-54.

Porfido, S., Esposito, E. ET AL. 2002. Areal distribution of ground effects induced by strong earthquakes in the southern Apennines (Italy). Surveys in Geophysics, 23, 529-562.

Richter, C. F. 1958. Elementary Seismology. W. H. Freeman, San Francisco.

Rodriguez, L. M., Audemard, F. A. \& Rodriguez, J. A. 2002. Casos històricos y contemporaneos de licuefacion de sedimentos inducidos por sismos en Venezuela desde 1530. III Jornadas Venezolanas de Sismologia Historica, Serie Tecnica, 1, 4-10.

SERVA, L. 1994. Ground effects in the intensity scales. Terra Nova, 6, 414-416.

SieberG, A. 1912. Über die makroseismische Bestimmung der Erdbebenstärke. Gerlands Beitrage Geophysik, 11, 227-239.

Silva, P. G., Rodríguez Pascua, M. A. et AL. 2008. Catalogación de los efectos geológicos y ambientales de los terremotos en España en la Escala ESI-2007 y su aplicación a los estudios paleosismológicos. Geotemas, 6, 1063-1066.

Slemmons, D. B. \& DePolo, C. M. 1986. Evaluation of active faulting and associated hazards. In: WALLACE, R. E. (ed.) Active Tectonics: Impacts on Society. National Academy Press, Washington, D.C., Studies in Geophysics, 45-62.

Wallace, R. E. 1986. Active Tectonics: Impacts on Society, National Academy Press, Washington, D.C., Studies in Geophysics.

Wood, H. O. \& Neumann, F. 1931. Modified Mercalli Intensity Scale of 1931. Bulletin of the Seismological Society of America, 21(4), 277-283.

Wesnousky, S. G. 2008. Displacement and geometrical characteristics of earthquake surface ruptures: issues and implications for seismic-hazard analysis and the process of earthquake rupture. Bulletin of the Seismological Society of America, 98(4), 1609-1632. 